\title{
O CINEMA-SONHO DE JOSÉ LUIZ ZAGATI
}

\author{
ENTREVISTA CONCEDIDA POR JOSÉ LUIZ ZAGATI, CRIADOR \\ DO MINI CINE TUPY, EM TABOÃO DA SERRA, A ALICE FÁTIMA \\ MARTINS' E J. BAMBERG²
}

Encontramos seu José Luiz Zagati no Mini Cine Tupy, pela primeira vez, na véspera do Dia das Crianças, em 11 de outubro de 2009. Naquele dia, ele estava preparando a programação especial para a data: projeção de filmes, distribuição de lanche e brindes, brincadeiras na rua. Durante a tarde, compartilhou conosco suas histórias com rara capacidade narrativa. No ano seguinte, ele participou da abertura do III Seminário Nacional de Pesquisa em Arte e Cultura Visual, na Faculdade de Artes Visuais da UFG. Em 2013, deparou-se com circunstâncias que o levaram a encerrar as atividades no cineminha. Em 2016, seu Zagati nos deixou. Foi projetar filmes e contar histórias em outros céus. A publicação desta entrevista é uma homenagem a ele. É também a oportunidade de compartilhar o seu próprio relato sobre esse trabalho tão potente, sobre sua experiência singular de viver a cidade e a condição de cidadania, a despeito das adversidades, em favor do cinema e da educação. Ao deguste!

J. Bamberg (JB): Seu Zagati, como foi a história da construção do Mini Cine Tupy?

ZAGATI: Em 1990, eu fiquei desempregado e comecei a catar papel para sobreviver.

\section{Alice Fátima Martins (AFM): Antes dis- so o senhor trabalhava com o quê?}

ZAGATI: Eu trabalhei com um pouco de tudo nessa vida. Fui servente de pedreiro, ajudante de trabalho em indústria, borracheiro, montador de acumulador de energia elétrica, baterias. Mas, em 1990, eu fiquei desempregado. Então, eu comecei a trabalhar catando papel. Foi aí que eu realizei meu sonho, o sonho que eu tinha desde quando eu fui ao cinema pela primeira vez, com cinco anos de idade, lá na cidade onde eu nasci, a cidade de Guaíba, perto de Ribeirão Preto. Eu nasci em 1950, no campo. Lembro que, num domingo, a minha irmã me levou ao cinema, no Cine São Mateus. Foi naquele momento que o cinema me fascinou... Era um filme de caubóis: o Billy the Kid. Lembro como se fosse agora! Era bom de briga, o Billy the Kid! (risos).

Bom, aí meu pai veio embora para São Paulo, ganhar um dinheiro para voltar e comprar um terreno lá. Mas meu pai acabou ficando por aqui. Ele comprou um terreno aqui mesmo e aqui fez uma casa. Minha mãe se empregou, e nunca mais voltamos. Aqui, no centro de Taboão, eu conheci o Cine Tupy. Na época, aqui tinha chácaras. No centro de Taboão da Serra todo mundo se reunia. Ali tinha o cinema, a igreja, o cartório... Então, tudo se resolvia por ali. Eu era pequeno, e estava sempre com meu pai. Meu pai ficava na padaria, tomando umas cachaças, e o cinema ali do lado. Eu ficava em

1 Professora na Faculdade de Artes Visuais da Universidade Federal de Goiás, no curso de Artes Visuais/Licenciatura, e no Programa de Pós-Graduação em Arte e Cultura Visual. Bolsista de Produtividade em Pesquisa pelo CNPq.

2 Pesquisador visitante do Programa Avançado de Cultura Contemporânea, da Universidade Federal do Rio de Janeiro, membro do Instituto Kaapikongo do Brasil de Dentro. 
frente ao Cinema Tupy, escutando o som do filme que vinha lá de dentro. Parece que foi ontem!

AFM: O senhor não via os filmes no Cine Tupy?

ZAGATI: Não porque era pequeno. Eu ficava só do lado de fora, olhando para o cinema e me imaginando lá dentro. Então: seis, sete, nove, oito anos... eu fui crescendo. Quando eu peguei uma certa idade, doze anos ou treze, passei a frequentar o Cinema Tupy. Eu ia para o Cine Tupy nos finais de semana. Nem sabia o que estava passando, mas ia, porque ia ao cinema. Nós morávamos na região das olarias. Eu ganhava algum dinheiro com as mulheres que tinham comércio. Eu enchia a caixa d'água delas durante a semana. Aquelas mulheres, como tinham um poder aquisitivo melhor, tinham caixa d'água com bomba em casa. Já nós tínhamos poço com corda e balde. Então, elas me chamavam para encher a caixa d'água e me davam umas moedas, que eu guardava para ir ao cinema no domingo. Eu pegava o ferro a brasa da minha mãe e passava a melhor roupa, porque ia ao cinema! Era maravilhoso!

Bom, o tempo passou. O Cine Tupy fechou em 1970, mais ou menos. As salas de cinema estavam fechando no Brasil inteiro, nessa época. Ele foi decaindo e decaindo, e acabou fechando também. Eu estava sempre lá no cinema. Sempre quis fazer plateia. Eu não eu queria fazer cinema, pois fazer cinema é uma outra coisa. Para mim, valia aquela lembrança de quando entrei no cinema e a primeira coisa que vi: o filme havia começado, aquela luz passando. A luz saía de lá e chegava na tela, e aquelas pessoas estavam sentadas lá assistindo filme. Me deu uma coisa. Olhei as pessoas, a luz do projetor, a tela... eu fico encantado com aquilo. Então, eu queria fazer aquilo. Foi a emoção de ver as pessoas assistindo ao filme e eu passando o filme. Porque eu sonhei passando filmes, toda a minha vida.
Bom, mas foi com o trabalho de catador de papel que eu consegui realizar. Eu comecei a encontrar pedaço de fita, rolo. Quando eu achava um pedaço de filme, para mim era um grande tesouro. Você sabe o que eu pensava? "Como é que isso foi jogado em um aterro sanitário, no lixão de Taboão?"

As reformas dos prédios estavam acontecendo no centro de São Paulo. Então, vinha aquele lixo de São Paulo, que era jogado aqui... Eles jogavam os entulhos das obras, dos prédios derrubados. $E$, junto, vinha o lixo das salas de cinema que estavam sendo derrubadas. Lixo de reforma de cinema. E eu acabei me envolvendo com isso. Eu fui guardando os pedaços de fitas que achava, e acabei me envolvendo com isso. Aquela coisa do Cinema Paradiso. Eu achava um pedaço de um filminho, e pensava: "Ah, eu vou guardar isso aqui porque isso é uma história!"

Eu encontrei no lixo a carcaça de um projetor de 16 milímetros. Não funcionava. Mas levei para casa. Eu estava mexendo com meu projetor quando passou um carro na rua. O camarada me viu mexendo com aquilo, e voltou dizendo: "Olha, eu tenho um projetor como esse teu aí". Aí eu falei assim: "você tem um projetor aí? Eu queria ver". Então, ele disse: "Você tem algum filme?" Eu falei: "olha, só tenho esses pedacinhos aqui!" Ele disse: "Leva na minha casa que eu vou te mostrar meu projetor". Levei lá e ele me mostrou o projetor, explicou como funcionava. Ele não vendia o projetor, porque, naquela época, ele passava filmes em igrejas. Ele passava filmes bíblicos, e ganhava dinheiro com isso. Mas ele comentou sobre um amigo dele, em São Paulo, que tinha um do mesmo modelo para vender. Comentou, mas não deu o endereço. Dias depois, ele me procurou querendo trocar a suspensão do carro. Como ele não tinha dinheiro para pagar, eu fiz o serviço em troca de um cartãozinho com o endereço do cara do projetor. Mas quando eu terminei 
o trabalho, ele não achou o cartão. Aí me deu a indicação mais ou menos, disse que era perto da Estação da Luz. Então eu fui procurar o projetor. Andei o dia todo, rua por rua, loja por loja de coisas usadas lá no centro, na Santa Efigênia, que tinha muitos usados. E era ali...na Rua Aurora. Falam que ali é a Cracolândia, né? Mas antes era a Cinelândia...

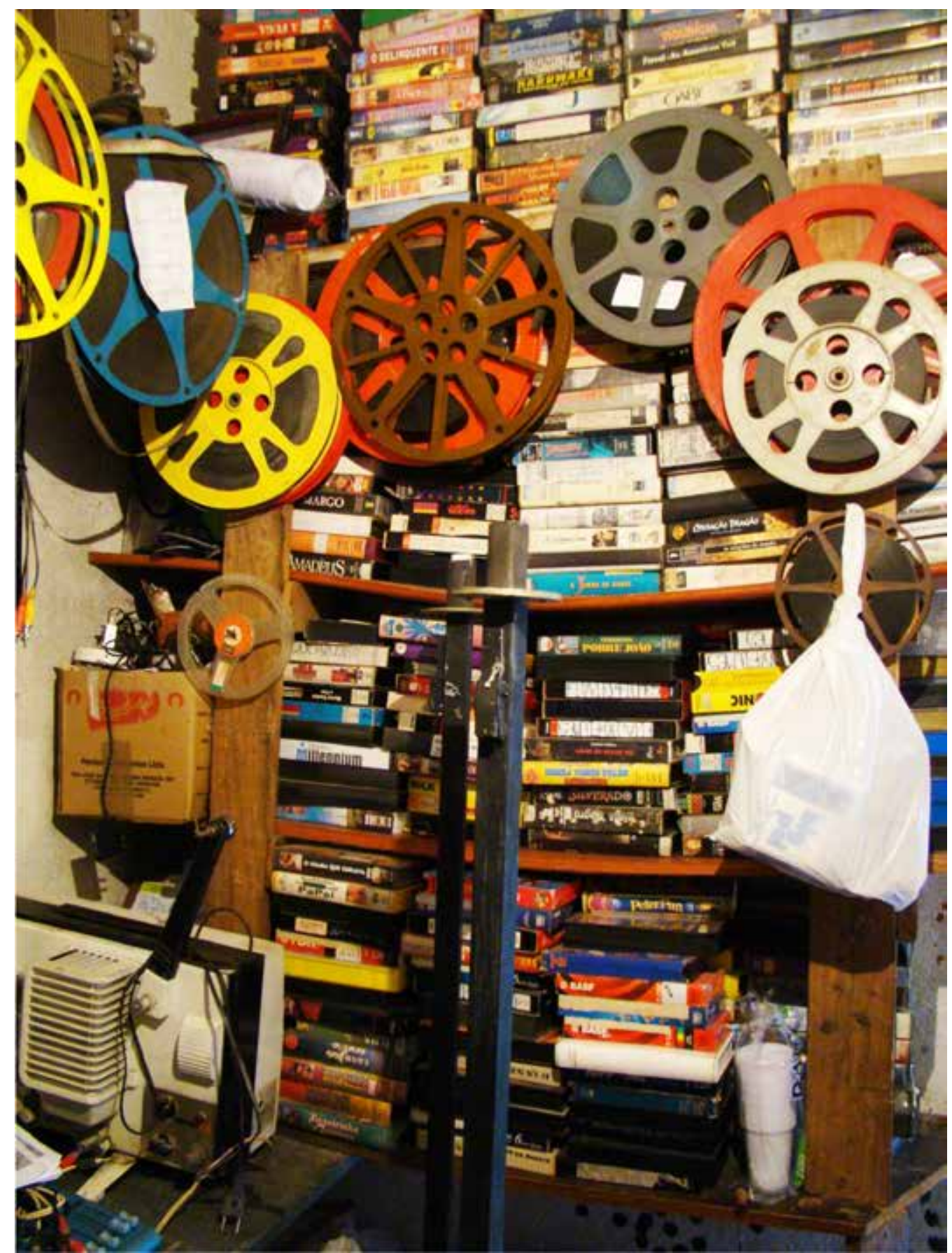

Acervo de filmes do seu Zagati. Foto: Alice Fátima Martins, 2009.

JB: Sim, ali era a Cinelândia antiga.

ZAGATI: Então, era uma lojinha de usados com coisas de um lado e do outro. Fui no balcão, lá no fundo, contei que estava procuran- do um projetor, expliquei o modelo. 0 dono da loja mostrou o que tinha. Então ele ligou o projetor para mim. Pegou um filminho e passou. Estava perfeitinho. Você nem imagina! Aí eu perguntei o preço. Eu não tinha levado di- 
nheiro comigo... e também não sabia o valor, não tinha uma ideia. Custava oitenta reais... Eu levei um susto, porque foi uma grande coincidência. Esse dinheiro eu tinha em casa. Se eu soubesse tinha levado comigo! Eu falei para o cidadão: “Ó, eu moro em Taboão da Serra. Eu vou buscar o dinheiro... Eu vou ali e já volto". Lá do centro não tem ônibus direto para Taboão. Aqui é município, então não tem o ônibus que vai até o centro de São Paulo. Eu peguei um ônibus que ia até a divisa de Taboão/São Paulo... Acabei de chegar a pé. Peguei o dinheiro em casa, e voltei para a cidade. Cheguei lá e disse: "eu vim buscar o projetor".

Eu não podia perder essa oportunidade. Dei os oitenta reais e ele me deu o projetorzinho. Vim de ônibus. Coloquei ele no colo como se fosse um bebê. Aí, quando cheguei em casa, ajeitei ele um pouquinho, peguei os primeiros pedaços de filme que eu havia juntado, e emendei. Aí eu pendurei um lençol, já de tardinha, pus uma mesinha lá na rua e botei o projetor com filme. Foi escurecendo e eu liguei... Surgiu o meu cinema!

Aí começaram a vir aquelas crianças, e todo mundo, assim... assim... "O que é isso Zagati?" Aí eles erguiam o pano, olhavam o projetor, e ficavam tão encantados com aquilo. Foi aí que começou, com aqueles pedaços de filmes...

Eu precisava de filme, né? Então eu voltei na loja onde comprei o projetor. O dono da loja falou que eu fosse procurar o seu Archimedes Lombardi, que é o presidente da Associação Brasileira de Colecionadores de Filmes de 16 mm. Era uma pista.

No sábado à noite, ouvi no rádio um cidadão falando sobre cinema. Ele estava contando que queria fazer um filme sobre o Mazzaropi, e as dificuldades, e coisa e tal. Mas ele fez o filme, e lançou um livro. E no final da entrevista ele falou sobre o Cine Clube do Bairro do Ipiranga, contando que ele era membro. Ficava no Bairro do Ipiranga, na Biblioteca Municipal
Genésio de Almeida Moura, era gratuito e funcionava aos sábados... Então, eu pensei que no sábado seguinte ia conhecer o Cine Clube do Bairro do Ipiranga.

E fui para o Bairro do Ipiranga, de ônibus. A porta da biblioteca estava fechada, era cedo ainda. Fiquei lá esperando. Umas cinco e meia da tarde parou um carro lá na rua. O camarada desceu, abriu o porta-malas, e começou a colocar uma coisa no chão. Eu pensei que devia ser o seu Archimedes, e fui falar com ele. Então, ele me disse: "dá para o senhor me ajudar a colocar isso aqui lá dentro?" o cine Clube não deixa equipamento lá, que é uma biblioteca. Ele tem que levar para casa.

AFM: Ele tem que levar e trazer os equipamentos toda vez?

ZAGATI: sim! Ele foi muito atencioso comigo. E eu passei a frequentar o Cine Clube do Ipiranga. Eu morava mais longe, mas era o primeiro a chegar. E um determinado dia ele falou: "Zagati, eu trouxe um presente para você". Me deu um longa-metragem, meio ruinzinho e tal, chamado "Cruéis dominadores". Foi o meu primeiro filme completo. Aí, quando terminou o filme que ele exibiu, eu vim embora para casa, para, no domingo, fazer a estreia do Mini Cine Tupy. O nome Mini Cine Tupy era em homenagem ao Cine Tupy.

De manhã, eu fiz a cartolina e anunciei aquele filme. Coloquei o título do filme, o diretor, direção, parte do elenco e tal. Aí anunciei o filme.

Era um domingo tão bonito, um dia bonito que parece que estava preparado para aquilo. E outra, parece que tinha coincidido com o pagamento, eu sou muito observador (risos). Tinha um movimento muito grande de pessoas fazendo compra e indo pra feira. Porque eu conheço, era coisa de pagamento que tinha saído. A gente percebe porque, quando não é dia de pagamento, fica todo mundo meio quietinho. 
Quando é dia dez, quinze, todo mundo gastando o dinheiro e ficam todas por aí. Quando foi de noite, ajeitei tudinho. Botei na rua o pano do cinema, e a rua encheu de gente. Eu não sei. Eu divulguei, né? Eu passei o filme, a primeira parte, com um medo danado de queimar a lâmpada porque esse projetorzinho queima. Um projetorzinho com uma lâmpada. O filme também pode arrebentar. Bom, era duas partes. Primeira parte tirei o rolinho, coloquei outro e foi sucesso total.

Tinha um barzinho perto, que vendia sal- gadinho, sorvete, do seu Barriga. Naquele dia foi sucesso. Todo mundo ali perto da lanchonete, ele vendeu muito a noite. No intervalo que eu troquei o rolo, o pessoal foi lá comprar uma cerveja e comentar o filme. O seu Barriga me disse: "olha aí Zé, o que precisar de comer e de beber aqui, é à vontade!" Ele me deu (risos).

Aí, terminei de projetar o filme. Deu um alívio! Deu tudo certo! Estava inaugurado o Mini Cine Tupy, em homenagem ao Cine Tupy, que faz parte da história de Taboão da Serra.

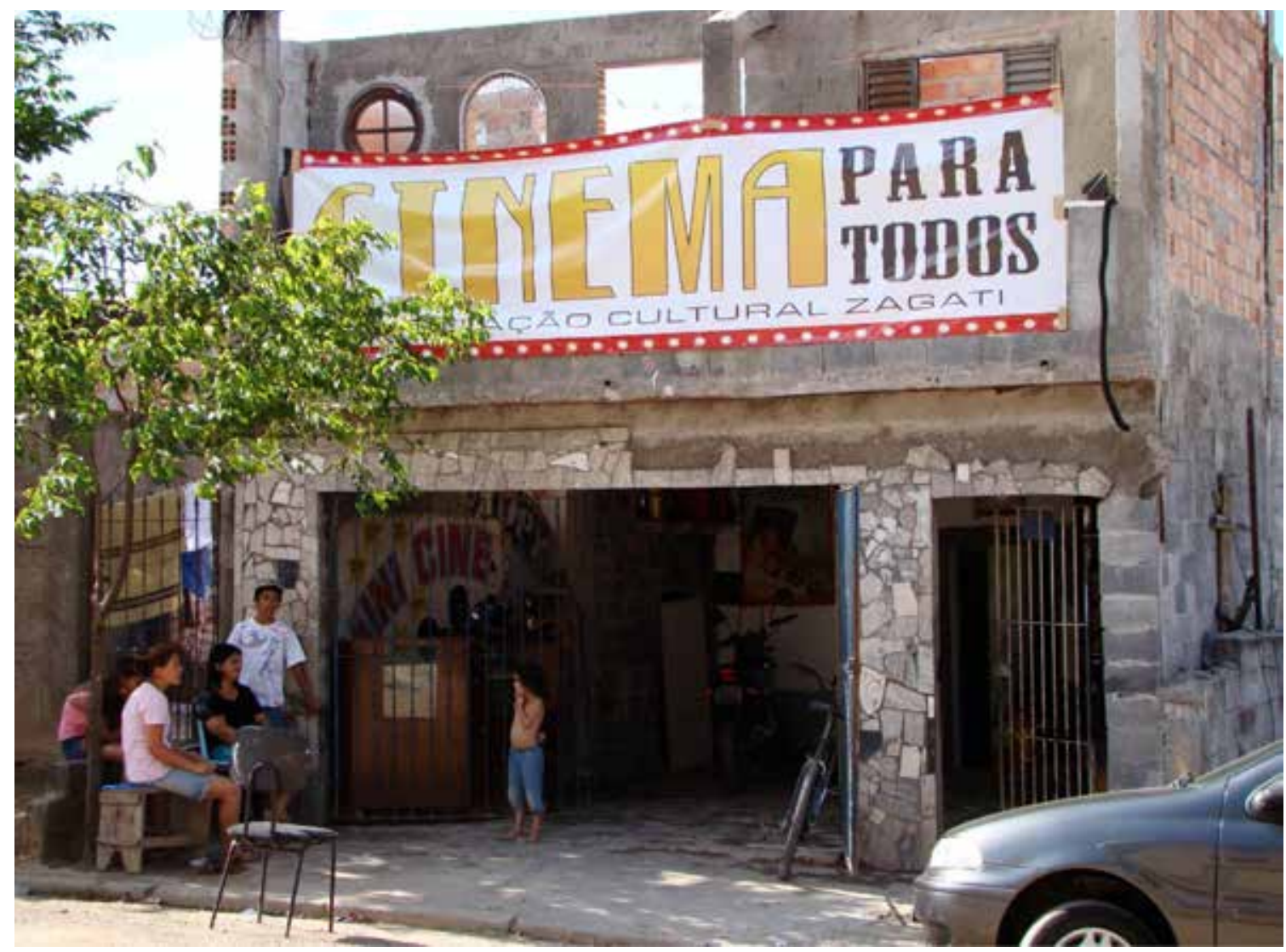

Frente do Mini Cine Tupy, em Taboão da Serra. Foto: J. Bamberg, 2009.

\section{B: E quando foi isso Seu Zagati?}

ZAGATI: Dia 16 de agosto de 1998 foi a estreia. Daí seu Archimedes começou a me emprestar os filmes. Ele é colecionador. $\mathrm{O}$ que eu passava era da coleção dele. Ele confiava em mim. Demorou para ele confiar em mim. Ele fala isso no documentário que a gente fez: “Eu não acreditava porque o Zagati é um catador de papel. Mas eu vi que ele persistia. Hoje ele é um grande parceiro". Aí ele me emprestava o filme e eu trazia, passava no domingo. No sábado seguinte eu levava para o Cine Ipiranga, e lá ele me emprestava outro. Por isso ele disse isso no documentário Zagati.

Todo domingo tinha um filme novo. Não um filme novo, um filme novo no modo de dizer... Era um filme velho de colecionador. Era um fil- 
me diferente. Então não me faltava filme, né? E assim foi...

AFM: O Cine Clube lá continua funcionando?

ZAGATI: Continua funcionando. E ele me ajudou muito, muito. Tem muita coisa aqui que ele me deu, né? Ele é muito amigo e parceiro. Eu continuei então fazendo esse trabalho. Só que aí aconteceu o seguinte: eu passo a semana trabalhando aqui em Taboão da Serra com meu carrinho, que dá o meu sustento e da minha família. O que acontece? Eu passava assim nos bairros, andando, e via espaço livre, assim, e via muita criança. Então eu falava para pessoas assim: "Olha eu gostaria de passar um filme aqui para as crianças". Os adultos, as mães das crianças olhavam para o meu carrinho, desconfiadas. Eu explicava que queria passar um filme para as crianças, que não queria nada além disso. Só precisava de um lugar para pendurar o pano, e uma tomada de luz. Eles gostavam. Então, no sábado, o seu Archimedes me emprestava o filme. No domingo, eu passava o filme para as crianças. Mas as vezes estava chovendo. Nossa! Eu me preparei a semana inteira, trouxe o filme, e no domingo estava chovendo! Então, eu não podia passar o filme. Algumas vezes eu tentei começar. Mas, antes da metade, chovia, e aí todo mundo saía correndo, e eu enrolando as minhas coisas com dificuldade.

Eu ficava reparando que as escolas estavam fechadas no domingo. Então, eu me imaginava lá dentro. Eu pensava na estrutura da escola: tem banheiro, tem cadeira! Puxa vida, mas ela estava fechada...

Um dia, pegando papelão na feira, eu achei um jornal que tinha o endereço da Secretaria de Educação e Cultura do município. Então, eu peguei o jornal, fui até um orelhão, e liguei para a Secretaria. Eu disse: "eu preciso falar com o Secretário de Educação", e a moça, do outro lado, respondeu: "o senhor tem que mandar um ofício, ou uma carta, porque isso não é assim...". Eu estava com o carrinho. Então, eu fui para casa, troquei de roupa, peguei o ônibus, e fui bater lá na porta da Secretaria. Eu levei o jornal que tinha o telefone e o endereço. "Eu quero falar com o Secretário". Falaram a mesma coisa, de novo. Eu insisti com o guarda. Sabe por quê? Eu achava que tinha o direito de falar. Eu sou cidadão, ele é o Secretário, e eu queria falar com ele.

\section{AFM: Com toda certeza, Seu Zagati!}

ZAGATI: Com muito custo me mandaram subir. Eu sentei e fiquei lá esperando. Aí me chamaram para falar com o Secretário. Disseram que eu tinha que ser rápido porque ele era muito ocupado. Eu pensei: "tem que ser rápido", então fui logo dizendo "Eu preciso de uma escola". O Secretário estranhou: "Para que você quer uma escola?" Então, eu expliquei: "eu passo filme para crianças, e chove, e tal, e tal..." Fui contando a história da chuva para ele. Aí ele mudou a conversa: "Opa, como é que é isso? Me explica melhor!" Eu me senti mais à vontade, e contei toda a história para ele, e ele gostou. "Dá para você fazer uma demonstração?" Ele quis saber, e disse: "olhe, vai ser em uma escola. Você monta. Vai lá, conversa com a professora, leva uma carta que eu vou mandar. Vai ser numa reunião de pais e professores". Aí eu fui. No dia combinado, eu levei tudo para a escola, e montei. Naquele dia eu levei um documentário gravado em Taboão da Serra, em 1965. Foi até o seu Archimedes que meu deu e disse que eu podia mostrar porque conta um pouco da história de Taboão da Serra. O filme chamava "Aliança para o almoço", que foi na época em que o governo levou a merenda para a escola. Ele conta a história de um menino que não se alimenta bem e não tem ânimo para estudar, as notas são muito baixas. Então, o pai dele vai tirar ele da escola e colo- 
car no trabalho porque o menino não aprende mesmo. Mas ele não aprende porque ele alimenta mal. Ele conta que o amigo dele que é bem alimentado vai bem nos estudos, e tal... Então, o filme fala que a merenda escolar ajuda bastante a criança. Então, eu passei aquele documentário. Quando terminou, eu peguei as coisas e coloquei na mala e vim embora porque eu estava trabalhando naquele dia.

Quando eu cheguei em casa, tinha um recado para eu ir na prefeitura imediatamente. Eu fui. O Secretário disse: "você tem o Teatro Municipal de Taboão da Serra para fazer uma mostra de cinema. Você tem três dias pra fazer uma mostra que é a primeira mostra de cinema desse tipo aqui em Taboão". É brincadeira! Pra quem tá com o carrinho de ferro velho, jogar o Teatro Municipal de Taboão da Serra para fazer a primeira mostra de cinema! Foi um desafio! Eu gosto que façam um desafio, sabe?

Então ele perguntou: "dá pra você fazer isso?" Dava. Aí a jornalista Cristina Aguilera veio em casa. Hoje ela é minha amiga. Ela fez a primeira chamadinha no jornal, desse tamaninho, dizendo: "Taboão terá a primeira mostra de cinema nacional". Ótimo! Aí eu procurei seu Archimedes: "Eu preciso que você me ajude em uma coisa aí. Me deram uma incumbência muito grande e eu preciso que você me empreste mais uns dois projetores de reserva, alguns filmes a mais". Ele falou para eu ir buscar. 0 pessoal da prefeitura deu uma perua e foi comigo lá no Ipiranga. Tudo que seu Archimedes me emprestou eu montei na segunda, terça e quarta. A prefeitura levava as crianças das escolas. Esse era o público. Foi um sucesso. As crianças das escolas vinham da periferia, vinham do centro, vinham as crianças especiais. Foi muito gostoso e eu fiquei muito feliz de ter acontecido aquilo.

No segundo dia, eles me falaram que eu ia ter uma surpresa. Foi quando o Canal 21 chegou lá. Pois é, a Cristina Aguilera e uma amiga estavam no Canal 21, e levaram a equipe, inclusive durante a noite.

AFM: O Canal 21 aqui é qual rede?

ZAGATI: É a Rede Bandeirantes.

ZAGATI: Então, à noite, imagina, a minha tela e a minha armação lá no palco... Não tinha nada de especial não, eu mesmo liguei as minhas coisas e montei. Ela chegou, com uma câmera, eu atento com o projetor. O filme era "Sangue ardente", um filme sobre um cigano. Nossa que apreensão! Ela com aquela câmera filmando tudo, e dizendo: "fique tranquilo, fique tranquilo". Aí, no fim, deu tudo certo. Terminou tudo na quinta, e eu voltei minha vida ao normal. Dias depois, eu estava me vendo na televisão. O pessoal dizia: "Vi você na televisão". E foi assim que todo mundo começou a me ligar, a vir atrás. Não foi minha intenção aparecer não. Olha, eu não gosto de usar a palavra "orgulho". Mas eu vou dizer, eu tenho orgulho de falar que levo o nome de Taboão da Serra. Foi a partir daí que deslanchou, eu virei documentário. Foi gente da França e da Alemanha vindo aqui. Depois disso, foi feito o documentário "Zagati". Depois foi feito o documentário "Mini Cine Tupy", que inclusive ganhou um prêmio em Goiás! Eu vi na televisão, todo mundo viu. Me ligaram dizendo que eu tinha ganhado um prêmio de 25.000,00. Mas quem ganhou foi o diretor Sérgio Bloch, que ficou com melhor direção. Eu mesmo não vi nada. Mas fiquei esperando e pensei: "bem que podia ser para a gente investir aqui..." Mas foi o Sergio Bloch que ficou com o dinheiro. Um ano depois, ele me ligou, falei com ele que eu fiquei sabendo. Aí foi quando ele me mandou 1.000 reais.

A diferença é essa, professora Alice... Existe muita gente que faz isso. Eu não tenho recurso. O recurso eu busco, com recurso pouquinho. Quando você quer fazer as coisas, dá para fazer com pouco... Eu já andei bastante. Andei 
pela Grande São Paulo, pelo interior, inclusive a cidade de Guaíba, onde eu sou nascido. Em 2003, no aniversário da cidade de Guaíba, a prefeitura me chamou e eu passei filme lá. Porque o nosso trabalho não é para levar cinema para quem tem condições, para quem tem acesso, e sim, para quem não tem acesso. É para levar cinema para hospitais, asilos de idosos, hospital psiquiátrico. Já fiz muitos, só pedia o transporte. Eu ia uma vez por semana, e fazia dois, três asilos por dia. Eu fazia um asilo de manhã, outro na parte da tarde e outro na noite, lá em São Paulo. Era tão lindo! O Christopher Perrone, que é da Alemanha, marcou de vir aqui fazer um documentário para uma televisão da Alemanha. Coincidiu de eu ir em um desses asilos. Ele veio de manhã e a gente foi. Ele filmou lá, tudinho. Nos asilos, eles ficam mais é dormindo. Às vezes eu penso que eles não estão vendo, sabe? Mas aí eles olham o filme que tá passando... Eles tão ouvindo tudo.

AFM: o senhor não tem feito mais projeção nos asilos?

ZAGATI: Não, depois eu saí da Secretaria do Estado. Eu fui contratado para exibir esses filmes. Em 2001, Marcos Mendonça era o Secretário de Cultura do Estado. Eles me chamaram, eu fui lá e dei uma entrevista para uma revista do Estado. Então, a Secretaria me contratou e eu fiquei uns cinco, seis anos, por lá, fazendo esse trabalho. Agora eu saí... Mudou o governo, eles queriam me contratar, não queriam me mandar embora e nem me exonerar. O salário era pouco. Eles queriam que eu fizesse trabalho interno, todos os dias, na Secretaria. Eu falei: “não quero isso. Eu gosto é de tá fazendo o meu trabalho na periferia, passar filme na favela". Passar filmes em várias favelas de São Paulo na noite, né? Eu quero é ficar no meio das pessoas. Eu quero é levar o cinema. Agora eu ficar trabalhando em uma salinha fechada?
Não é isso que eu quero. Eu quero é o meu trabalho... Aí eu falei: "tô fora!"

Eu gosto é de dividir com as pessoas. Eu fico tão feliz por tantas pessoas que eu conheci aqui em Taboão da Serra e fora de Taboão da Serra: jovens, pessoas de idade que nunca foram ao cinema. Aqui perto, em Cotia, eu fiz doze dias um trabalho ali! Cinema no bairro. Primeiro no centro, depois no Bairro de Caucaia, que é afastado. No último dia, eu passei um filme do Mazzaropi que foi feito lá. Eu fiz uma programação, só filmes do Mazzaropi. Toda noite um carro da prefeitura de lá vinha me buscar. Eu levava o carrinho de pipoca e ficava fazendo pipoca, e punha meu filho para passar o filme. Muito legal.

Então, o pessoal de Caucaia, falava assim: "o Mazzaropi fez um filme aqui, o Chico Fumaça, eu quero ver!" Aí eu pesquisei, num livro, num dicionário de filmes, e descobri qual era o filme. Eu tenho o filme aqui, é um $16 \mathrm{~mm}$ que eles encontraram num almoxarifado. Chama "A romaria de Caucaia", feito em 1900 e lá vai bolinha. A japonesa que eu conheci que mora lá, bem velhinha, no filme, era bem moça. Ela ia de bicicleta na romaria de Caucaia e de Caucaia para Morrinhos de Pirapora, sabe! Então, eles na romaria, então eu vi aquele filme mudo, aquele filme caseiro, sabe! Uns iam de bicicleta, outros de carroça, outros de cavalo e ela, a japonesa, ia de bicicleta. A velhinha não anda mais.

Essa cultura do cinema... Eu fico muito feliz de ver aqui em Taboão da Serra as crianças que, na época que a gente começou, estavam pequenininhos. Hoje, eles me conhecem, eu encontro eles na rua. Se venho com peso nas costas, vira aquele menino: “ó, Zagati, deixa eu ajudar para você!" Outro me diz: "olha, Zagati, eu estou fazendo faculdade, por causa do cinema, entendeu?! Bom eu ter te conhecido". (Se emociona). Eu fico felicíssimo, eu sou muito grato, sabe? A minha passagem aqui é mo- 
desta, eu estou tentando ser útil. Eu não sei se eu consigo, mas eu fico muito feliz de ver meninos, mocinhas já, rapazinhos falando isso para mim.

AFM: O senhor está falando do trabalho que faz, indo para as escolas, indo para outras instituições, formando pessoas, falando da satisfação de ver dessa meninada crescendo, esse é um trabalho de muito valor. Quantas pessoas que têm condições, que têm estrutura e que fazem tão pouco...

ZAGATI: Aqui em Taboão da Serra tem o shopping. Mas veja, o cinema fechou em 1970. Quando o shopping foi construído, o Mini Cine Tupy já estava funcionando. E nem todo mundo vai ao shopping para ver um filme, né? É caro, distante, e as pessoas não têm dinheiro. Depois tem a condução. Quem tem carro tem que pagar estacionamento. Os filmes que passam lá, a gente passa aqui, embora atrasados. Eu pego numa locadora. Primeiro, o filme corre no cinema. Depois, eu passo ele aqui. "Cidade de Deus", por exemplo, eu passei aqui. Eu fiz duas sessões. E naquele dia ele estava concorrendo ao Oscar, lá nos Estados
Unidos. Eu convidei um jornal. A jornalista da Folha de São Paulo esteve aqui e fez a matéria. Lotou! A jornalista perguntando para as crianças se já tinham ido ao cinema. Elas respondiam que não, porque os pais não tinham dinheiro. Quando eu vejo isso em uma matéria eu fico... né?! Não dá mesmo, essa é a vida na periferia. Como é que o pai ou a mãe vai levar duas ou três crianças ao cinema? Nem pai nem mãe teve oportunidade de levar as crianças ao teatro. 0 pai e a mãe nunca foram ver uma mostra de arte. Então, alguém já vem com aquele costume e o filho também não aprende, está entendendo? Os filhos crescem e também não vão... Mas, às vezes, o pai fala que não dá, e dá... Às vezes, ele diz que não dá para levar o filho para ver o filme, mas ele bebe cinco ou seis cervejas em um bar. Tem esse problema.

Leva a criança um dia no teatro, no cinema... Ela cresce. Ela vai se educar. Agora, deixa aí, ao Deus dará, fica abandonado, cresce correndo o risco de virar marginal. Então, a gente tem que mostrar para eles que é possivel. Eu acho assim. Para a frente, quantas crianças vão se lembrar do Mini Cine Tupy?

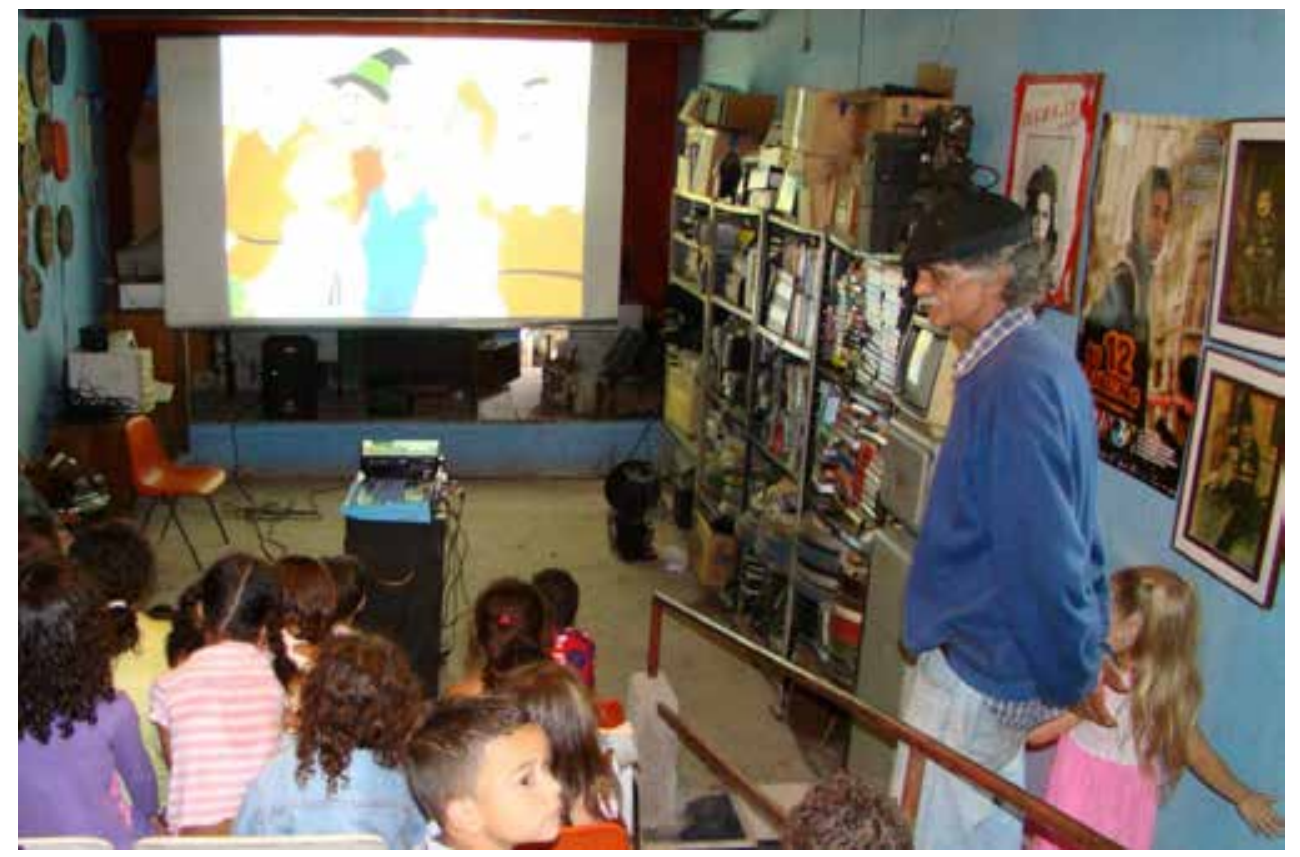

Seu Zagati, durante projeção de filme para crianças, no Mini Cine Tupy.

Foto: J. Bamberg, 2009. 
JB: $O$ trabalho de mostrar filme nas escolas, depois que você saiu da Secretaria, ninguém continuou fazendo?

ZAGATI: Então, a secretaria me procurou há um tempo, eu fiz um trabalho. Comecei fazendo um projeto chamado "Situação Cultural", que é da prefeitura de Taboão da Serra. Então, a gente começou a fazer cinema nas periferias, ótimo! Esse é lindo! Eu dentro das favelas, dentro das comunidades, as pessoas saindo de dentro dos barracos, vindo para a rua. No mês passado, eu fiz quatro apresentações fora. Não é só entretenimento. É educação através do cinema. Então é muito bom!

AFM: Seu Zagati, agradecemos muito ao senhor, por nos acolher no seu Cinema, por nos contar sua história.

ZAGATI: Eu é que agradeço a visita de vocês, né? De repente, vocês vão embora e eu ficando pensando: "será que eu falei demais?" Mas estou tentando falar tudo o que lembro. Afinal, vocês vêm de tão longe, lá de Goiás! Eu preciso contar tudo, não é? 